This item was submitted to Loughborough's Research Repository by the author.

Items in Figshare are protected by copyright, with all rights reserved, unless otherwise indicated.

\title{
Existing science on human factors and ergonomics in the design of ambulances and EMS equipment
}

PLEASE CITE THE PUBLISHED VERSION

https://doi.org/10.1080/10903127.2019.1568651

PUBLISHER

Taylor \& Francis

VERSION

AM (Accepted Manuscript)

PUBLISHER STATEMENT

This is an Accepted Manuscript of an article published by Taylor \& Francis in Prehospital Emergency Care on 2019-02-20, available online: https://doi.org/10.1080/10903127.2019.1568651

\section{LICENCE}

CC BY-NC-ND 4.0

\section{REPOSITORY RECORD}

Du, Bronson, Michelle Boileau, Kayla Wierts, Sue Hignett, Steven Fischer, and Amin Yazdani. 2019. "Existing Science on Human Factors and Ergonomics in the Design of Ambulances and EMS Equipment". figshare. https://hdl.handle.net/2134/36642. 


\section{Existing science on human factors and ergonomics in the design of ambulances and EMS equipment}

\begin{tabular}{|r|l|}
\hline Journal: & Prehospital Emergency Care \\
\hline Manuscript ID & UPEC-2018-0426.R2 \\
\hline Danuscript Type: & Original Contributions \\
\hline Author: & O4-Jan-2019 \\
\hline Complete List of Authors: & $\begin{array}{l}\text { Du, Bronson; University of Waterloo, Kinesiology } \\
\text { Boileau, Michelle; University of Waterloo, Kinesiology } \\
\text { Wierts, Kayla; University of Waterloo, Kinesiology } \\
\text { Hignett, Sue; Loughborough University Loughborough Design School } \\
\text { Fischer, Steven; University of Waterloo, Kinesiology } \\
\text { Yazdani, Amin; Conestoga College Institute of Technology and Advanced } \\
\text { Learning, School of Business; McMaster University, School of Geography } \\
\text { and Earth Sciences; University of Waterloo School of Public Health and } \\
\text { Health Systems }\end{array}$ \\
\hline Keywords: & $\begin{array}{l}\text { human factors and ergonomics, emergency medical services, } \\
\text { ambulances, EMS equipment }\end{array}$ \\
\hline
\end{tabular}

\section{SCHOLARONE ${ }^{m}$ Manuscripts}




\title{
Existing science on human factors and ergonomics in the design of ambulances and EMS equipment
}

\author{
Authors: Bronson Du ${ }^{1,2}$, Michelle Boileau ${ }^{1}$, Kayla Wierts ${ }^{1}$, Sue Hignett ${ }^{3}$, Steven Fischer ${ }^{1,2}$, \\ Amin Yazdani ${ }^{4,5,6}$ \\ ${ }^{1}$ Centre of Research Expertise for the Prevention of Musculoskeletal Disorders (CRE-MSD), \\ Waterloo, Ontario, Canada \\ ${ }^{2}$ Department of Kinesiology, University of Waterloo, Waterloo, ON, Canada \\ ${ }^{3}$ Design School, Loughborough University, Loughborough, United Kingdom \\ ${ }^{4}$ School of Business, Conestoga College Institute of Technology and Advanced Learning, \\ Kitchener, ON, Canada \\ ${ }^{5}$ School of Geography and Earth Sciences, McMaster University, Hamilton, ON, Canada \\ ${ }^{6}$ School of Public Health and Health Systems, University of Waterloo, ON, Canada \\ Corresponding author: Amin Yazdani \\ Email: ayazdani@conestogac.on.ca
}




\begin{abstract}
Background: Emergency medical services (EMS) personnel face a disproportionally high risk for fatality and injury due to the nature of their work; and current ambulance and EMS equipment design standards do not adequately safeguard EMS personnel from sacrificing personal safety for patient care, a known human factors and ergonomic (HFE) design challenge. Despite the desire to include HFE interventions or considerations into a standard, the effectiveness of existing HFE interventions for EMS is unclear. Objective: Therefore, this study aimed to synthesize the peer-reviewed literature on the design features of patient compartments and EMS equipment that affect EMS personnel's performance or well-being. Methods: A scoping review methodology was applied to systematically search and screen for relevant articles, and extract data. Three databases (EmBase, Scopus and PubMed) were searched, and search results were screened for articles that pertained to the performance or well-being of EMS personnel when interacting with the patient compartment or its associated equipment. Results and Discussion: Of the 4125 search results, 48 relevant articles were retained, and then sorted into one of three categories: general design, patient handling, and patient transport. It was concluded that, although research has progressed over the past 15 years, more research, development, and resources are needed. Newer generations of ambulances have not been shown to be safer during collisions and there is a knowledge gap in how occupants and contents of a patient compartment behave during a collision. Crash-tests have been performed with restrained occupants and supplies, however, that scenario is unrealistic in the field. While the existing literature provided initial ideas and innovations for improving the HFE of patient
\end{abstract}


handling and patient transport, it is important for future research to convey findings in a manner that can be used to inform design standards.

Keywords: human factors and ergonomics, emergency medical services, ambulances, paramedic equipment

Funding Details: This work was supported by the Canadian Safety and Security Program under Grant CSSP-2016-CP-2285.

Disclosure Statement: The authors report no conflict of interest. 


\section{Introduction}

In 2002, Maguire et al. uncovered a 'hidden crisis' within the emergency medical

services (EMS) industry, revealing that, relative to the US national average, EMS personnel were

2.5 times more likely to die on the job (1). Studies further found that, EMS personnel were 2.9

times more likely to suffer from injuries that required time away from work, and 13 times more

likely to suffer from low back pain when compared to other industries $(2,3)$. Considering the

complex and dynamic work, the elevated fatality and injury rates may not be surprising. For

example,an EMS personnel may need to provide patient care while being transported to the

hospital, and if the occupants or equipment have not been properly restrained, sudden changes

in acceleration, such as a collision, could cause serious injuries or even death $(1,4-7)$. The

frequent need to extricate and transfer patients on to and off of backboards, stretchers and

stair chairs also expose EMS personnel to human factors/ergonomic (HFE) hazards, such as high

forces, awkward postures, and repetitive movements (7-14). Although the essential tasks of

patient handling, care, and transport cannot be eliminated, the design of the ambulance and its associated equipment, which play a significant role in how EMS personnel interact with their patients, is modifiable.

Since EMS personnel use the ambulances and equipment that are provided by their employers, they often rely on manufacturers and procurement personnel to consider their interactions with the work system, i.e., core principles of HFE, when designing or purchasing products. However, these principles are rarely considered adequately because HFE guidelines, standards, and research specific to ambulances and EMS equipment are either not readily accessible or applicable $(15,16)$. On the contrary, ambulance and EMS equipment design 
standards, which are mandated and used as a basis for communicating design requirements, provide limited guidance of HFE principles. Therefore, our objective is to make HFE considerations specific to ambulances and EMS equipment more accessible and applicable to manufacturers, procurement personnel, and policymakers by synthesizing the relevant HFE literature into one document. A secondary objective is to identify areas for future research.

\section{Methods}

Our research adopted the framework for scoping reviews. Although scoping reviews do not assess the effectiveness of an intervention or the quality of the literature, they are useful for examining the extent, range and nature of research activity, as well as identifying research gaps. The framework for scoping reviews consist of 5 stages: identify the research questions; search for relevant studies; select relevant studies; chart the data; and collate, summarize and report the results $(17,18)$.

Identify the research questions

1. What is the state of research pertaining to HFE interventions or design features for patient compartments or EMS equipment?

2. What are the design gaps, recommendations and factors to consider for the patient compartment and EMS equipment mentioned in the scientific literature?

Search for relevant studies

We systematically searched three databases (PubMed, Scopus, and Embase) for articles related to how EMS personnel interacted with their ambulances and equipment, and the design of these products. For our search strategy, we identified three core concepts: EMS personnel, HFE, and ambulance and EMS equipment. Then for each concept, we generated a list of search terms (see supplementary materials for search terms). Using Boolean operators 'AND' between 
concepts, and 'OR' between search terms within a concept, we ran the systematic search on May $2^{\text {nd }}, 2017$, which resulted in 4125 articles (duplicates removed).

Select relevant studies

To filter out irrelevant search results and retain potentially relevant ones for full-text review, we developed a screening tool. The screening tool was a set criteria designed to only retain articles that directly targeted the EMS personnel population AND focused on either the design of the patient compartment/equipment OR the interaction between the EMS personnel and the patient compartment/equipment (see supplementary materials for screening tool). Articles on training, software applications, treatment protocols, and specialized ambulance vehicles were excluded.

To ensure the reliable application of our screening tool, three reviewers (coauthors BD, $\mathrm{MB}$, and $\mathrm{KW}$ ) independently applied the screening tool to a set of 200 titles and abstracts (ti/ab), then met to discuss whether or not each ti/ab satisfied the screening tool's criteria for inclusion. Discrepancies in the inclusion/exclusion of a ti/ab based on the application of the screening tool were discussed until consensus was reached. We repeated this process ( 3 times) until there were less than $10 \%$ discrepancies between $\mathrm{BD}, \mathrm{MB}$ and $\mathrm{KW}$ 's initial assessment of a ti/ab. The remaining ti/ab were then divided equally amongst the three reviewers to finish screening. Similarly, when the inclusion/exclusion of a ti/ab was unclear based on the screening tool, it was brought up for discussion with the reviewers until consensus was reached. Ti/ab where consensus could not be reached were retained for full-text review. 
Chart the data

Each retained article underwent full-text review by at least two of the reviewers where key data were extracted and charted using Excel (Microsoft, Redmond, Washington). We extracted 1) general information, which included the authors, publication year, study location, and component of ambulance/equipment; 2) study population, which included the participants' occupation and sample size; and 3) study characteristics, which included the research objectives, study design, and the independent/dependent variables (when applicable). Design issues, recommendations, or additional design considerations were extracted as well.

In addition, the retained articles were categorized into one of the six steps to quality intervention development (6SQuID) (19). The 6SQuID was created as a model to guide the development of public health interventions (19). The steps are as follows:

1) define and understand the problem and its causes

2) identify modifiable causal or contextual factors that have the greatest scope for change and identify who would benefit most

3) decide on the mechanisms of change

4) clarify how the intervention will be delivered

5) test and adapt the intervention

6) collect sufficient evidence of effectiveness to proceed to rigorous evaluation Application of the 6SQuID offered a framework to describe the state of the literature on the development of HFE interventions for EMS personnel, and to distinguish between research that described or identified the problem space (which could be used to inform interventions) from research that may have actually evaluated interventions (in a pilot or full launch). 
Collate, summarize, and report the results

Results are presented in four sections. An overview of the retained articles organized into the 6SQuID model is first presented, followed by each of the three categories that the articles were sorted into: general design, patient handling, and patient transport. General design discusses design problems and potential solutions for EMS with no particular focus; patient handling summarizes the research on the use of patient handling equipment such as cots, backboards, and stair chairs; and patient transport describes the design considerations that affect EMS personnel during patient transport, which included the workspace and layout, storage, crashworthiness, and restraints of the patient compartment.

\section{Results}

Overview

Forty-eight relevant articles were identified through the systematic search and screening process (Figure 1). The categorization of the articles according to the 6SQuID model suggested that the development of EMS interventions is in its early stages. Most of the research (55\%) focused on understanding the problem space and identifying modifiable risk factors; whereas less (22.5\%) focused on developing and implementing new interventions. Similarly, $22.5 \%$ of the articles evaluated novel interventions (Figure 2). According to the timeline of the research area, almost $90 \%$ of the articles were published after the reveal of the 'hidden crisis' in 2002, further supporting its infancy.

General Design

All articles triaged into general design $(n=10)$ acknowledged that the high rates of injury or death in the EMS occupation were attributable to the complex prehospital environment, and 
the compromising ambulance and EMS equipment designs (Table 1). The need to develop better design standards was mentioned in eight articles. Articles stated that there were "no science-based standards that governed ambulance patient compartment design and safety" (20), and that including HFE principles and research into ambulance "design, construction, and performance standard[s] would provide a baseline for improving safety, ergonomics and emergency medical care..." (21). Further, the lack of detailed standards limited compatibility between EMS services as they often had to develop their own specifications. For example, there were over 40 different ambulance designs in the UK prior to implementation of the Medical Vehicles and their equipment - Road ambulances standard (CEN 1789:2007) (22). Ultimately, design standards have not safeguarded ambulances from 'organically evolving' into a system that is neither effective nor efficient (23). These articles emphasized the need for design standards that are evidence-based and considers HFE.

Patient Handling

Articles sorted into patient handling included loading systems $(n=2)$, cots $(n=9)$, backboards $(n=2)$, stair chairs $(n=4)$, and other patient handling accessories $(n=8)$ (Table 2$)$. Four articles studied multiple types of patient handling equipment.

\section{Loading Systems}

Between the tail-lift, easi-loader, and ramp/winch loading systems, no optimal system was identified as each had their pros and cons. For example, the easi-loader, though efficient, required significantly greater forces and perceived exertion compared to the tail-lift system, a system that, however, required double the time to operate (24). Use of the ramp/winch system also exceeded spinal compression failure limits, but was capable of loading both cots and stair 
chairs (25). Future loading systems should strive to optimize speed, ease of use, access and physical demands.

\title{
Cots
}

Studies related to cot design generally supported powered over manual features $(26,27)$, cot legs that folded individually rather than simultaneously $(10,28,29)$, and handles that were designed for both grip and comfort (30). Although powered cots were expensive, heavy and could not be used in many environments, their implementation reduced stretcher-related injuries by over $70 \%(26,27)$. However, for EMS services that did not have the funding for powered cots, manual cots with legs that retracted independently required less lifting forces and effort because the non-retracted leg could support a large proportion of the cot's weight while (un)loading $(28,29)$. Lastly, the specific shape, material and texture of the cot's handles should be considered to reduce pressure points while ensuring sufficient grip (30). Soft rubber handles with pronounced naps on a textured surface improved grip but increased the risk of tender spots and blisters; while handles with less pronounced naps decreased the risk of pressure points, but had less grip (30).

\author{
Additional Stretcher Accessories \\ Compared to carrying a stretcher down the stairs, use of the descent control system, \\ which converted the stretcher carry task to a roll task, reduced spinal muscle activity, heart \\ rates and perceived exertion (31). Its integrated brakes also allowed for rest breaks and better \\ control. However, stair chairs were typically used for stair-transport, not stretchers (31).
}


For longer distance stretcher carries, use of shoulder straps reduced heart rate and cortisol concentrations, suggesting that it may decrease EMS personnel's physical stress levels (32).

\section{Backboards}

Rather than focusing on EMS personnel's interactions with backboards, these studies mainly focused on the patient. One article described the development, design and evaluation processes of a paediatric immobilizer, noting that current backboards did not provide proper spinal immobilization for infants and children due to their low weight and size (33). Another study evaluated vacuum splints as an alternative to traditional backboards based on speed of application, level of immobilization and patient comfort, noting that uncomfortable backboards may cause unnecessary radiological procedures because of undistinguishable pain caused either by trauma or the backboard (34). The study did find that EMS personnel could immobilize patients faster on vacuum splits than on traditional backboards (34).

\section{Additional Backboards Accessories}

During stair descents with a backboard, tall and heavy patients commonly slid forwards and hit the EMS personnel's chest; two studies suggested helpful accessories (31,35). One option was to add a foot-strap to the backboard; this successfully prevented patients from sliding down, which allowed EMS personnel to hold the backboard closer to their bodies and reduce their spinal loads. Another option was to use the backboard wheeler (similar to the decent control system) to convert the backboard carry task to a roll task (31). 


\section{Stair Chairs}

One study evaluated stair chair handle lengths based on muscle activity, heart rate, posture, task duration and perceived exertion. The study found that shorter handles forced EMS personnel to hold their hands further away from their bodies to maintain distance from the patient; and longer handles were problematic for short individuals because they needed to exert more shoulder activity to hold the stair chair high enough to clear the stairs (31). No optimal handle length for the stair chair was identified.

\section{Patient Handling Accessories}

Slide Boards and Rods

A series of four articles developed and implemented an innovative set of tools, slide boards and rods, to address the awkward postures and high forces used in traditional lateral bed-to-stretcher transfers. In traditional transfers, one-EMS personnel would kneel on the bed, and using the bedsheet, he/shethey would lift and push the patient towards the stretcher, while another other EMS personnel pulled from the stretcher side. With the use of the slide board, a low friction interface that bridged the gap between the bed and the stretcher, biomechanical forces and perceived exertion was-were reduced (36). Further, rolling rods into the bedsheets made gripping the sheets easier and allowed both EMS personnel to stand by the stretcher rather than having one kneel on the unstable bed. However, there was a fear that, if both EMS_-personnel pulled from the stretcher side, the patient would roll off the other side of the bed (36).

Although slide boards and rods were generally well-received by the study participants (EMS personnel), other factors affected its voluntary adoption into the field (37). The various factors of adoption included supportiveness of the innovation, ease of use, relative advantage, 
task-technology compatibility, perceived adequacy of training, optimistic bias, attitude towards use and intentions to use. This series of studies demonstrated that the design of an accessory needed to be more than biomechanically effective for it to be adopted into the work system.

\section{Transfer Slings}

Two articles suggested the use of transfer slings to facilitate patient transfers from a seated position, an inherently difficult task with high levels of spinal loading. In the traditional under-axilla lift, the EMS personnel must contact the patient, which increases their risk of receiving a transmittable disease (38). Further, dealing with patients who are wearing light sleep wear or soiled garments places the EMS personnel in awkward postures, as they perform lifts while considering the patients' dignity (38). As an alternative to the under-axilla lift, transfer slings were viewed favourably by the study participants (EMS personnel) because it allowed them to face away from the patient and avoid close contact (38).

\section{Patient Transport}

Eighteen articles were related to design features that affected EMS personnel during patient transport to definitive care (Table 3). Articles in this section included topics on crashworthiness $(n=3)$, workspace and layout $(n=6)$, restraints $(n=5)$, and storage $(n=4)$.

\section{Crashworthiness}

Within this set of articles, there was a case study that provided a list of safety features to look for when purchasing ambulances (39); a literature review that described the frequency, epidemiology, etiology, typology and cost of ambulance crashes (40); and a crash-test which concluded that each piece of equipment should be secured to 10Gs of three-dimensional force (41). The literature review emphasized the importance of the structure, placement, and safety 


\begin{abstract}
of seats within the patient compartment, along with other educational, administrative and engineering controls (40). Although few articles directly researched crashworthiness, it was an underlying design consideration for many articles found in other subcategories (workspace and layout, and restraints).
\end{abstract}

\title{
Workspace and Layout
}

These studies focused on the positioning of the EMS personnel, equipment and patient to interact with one another safely and efficiently. Core objectives were to make the patient, equipment and tools readily accessible to the EMS personnel in order to reduce awkward postures and increase use of restraints (8). Novel simulations and design requirements have been developed, but an optimal design is yet to be available. Two articles $(9,12)$ provided specific requirements and recommendations for the design of the patient compartment. Byran and Gilad (2012) even provided precise dimensions for their suggested design and layout (9). Other issues identified included low overhead clearances and limited leg room, which increased the risk for head and knee strike injuries, respectively.

\section{Restraints}

Studies categorized into restraints described EMS personnel's perceptions and use of restraints $(42,43)$, explored various restraint systems for safety and functionality $(44,45)$, and presented a case for including child/infant specific restraint systems (46). The main design challenge for restraints were developing a system that balanced the trade-offs between ensuring that EMS personnel were secured during sudden accelerations/decelerations while enabling them to provide patient care. If restraints limited access to the patient or necessary equipment, EMS personnel often choose not to use restraints $(21,23)$. 
In the past, seatbelts were too restrictive and limited patient care. The traditional lap belt, for example, required EMS personnel to be seated with their backs against the seatback; this prohibited the EMS personnel from moving to the edge of the seat to access the patient, retrieving supplies from across the compartment, and performing life-saving procedures that required standing or kneeling. Current research on developing a more functional restraint system recommended to incorporate pelvic retractors to the system, and chest and shoulder tethers for better weight distribution across the hips (44). Although improving seatbelt designs are essential to increasing its usage, other factors such as EMS personnel's attitudes toward restraints and the accessibility of equipment from a seated position also played a significant role.

\section{Storage}

Rather than describing how drawers or cabinets should be designed, studies in this category looked at simplifying medication storage to reduce the risk of prescription errors. One article suggested to standardize medication storage including how they were stored and at what concentrations (47). Another article looked at using radio frequency identification tags to electronically track medications and provide two-way communication for parties involved with patient care (48). Also, a colour-coding system was shown to reduce dosing errors (49). Standardized and simple systems improved outcomes, especially for unique or specialized patients (49). 


\section{Discussion}

Overall State of the Ambulance and EMS Equipment Research

Through our review of the literature pertaining to the design and use of the patient compartment and EMS equipment, we found that this research area has only gained momentum within the past 15 years, and that evidence-based interventions were scarce. As categorized by the 6SQUiD model, the majority of research focused on understanding and describing the complexities and demands of EMS work. Research in these initial stages of the 6SQUiD (steps 1 and 2) are essential to identifying the underlying design factors for preventable work-related adversities and designing interventions that would be most impactful and integrable to the EMS work system. Despite having fewer studies aimed at developing, implementing and evaluating novel interventions, we have identified important research gaps, successful interventions, and valuable lessons for discussion.

State of Patient Handing Research

Many lessons can be gleaned from the research on transferring patients from the emergency scene into the ambulance. For transferring a patient from a seated posture, transfer slings were recommended. For transferring a patient from a bed to a stretcher, the novel slide board, which removed the gap between the bed and the stretcher, significantly reduced physical demands compared to traditional bedsheet transfers. For transferring a patient down the stairs, either adding a foot-strap to the backboard or converting the carry task to a roll task (using the descent control system or the backboard wheeler) was effective in reducing forces. Although these accessories were effective in controlled lab settings, they have not been widely adopted in the industry to enable field evaluations. 
One ilnterventions that have been implemented in the field and demonstrated large reductions of stretcher-related injuries were powered cots and loaders. Rather than manually lifting/lowering the cot into and out of the ambulance, powered cots can accomplish this with the push of a button (26). However, not all powered cots worked the same. Depending on whether or not the ambulance had a powered loader, variations in the design of the powered cot affected physical demands. For example, when a powered loader was not present, powered cots with legs that fold independently required less forces to (un)load compared with powered cots with legs that fold simultaneously (similar to manual cots) (28). However, when used in combination with powered loaders, powered cots with legs that folded simultaneously required even less exertion (50). Additional improvements to powered cots include reducing the weight to allow for better maneuverability and increasing its adjustability to fit patients of varying sizes.

State of Patient Transport Research

Articles related to patient transport emphasized that providing patient care during transport was unavoidable, and that those scenarios were fraught with hazards. Hazards included the frequent handling of sharps, and working in a confined workspace that did not facilitate access to necessary items (patient and equipment), or use of seat-belts. Addressing these hazards within the patient compartment required a holistic approach to ensure that all components worked synergistically. Therefore, task analyses were strongly recommended when designing the patient compartment. Researchers agreed that to improve the HFE of patient transport, there needs to be a combination of developing restraints that allowed EMS personnel to retrieve supplies and provide patient care, designing layouts that prioritize the 
accessibility of the patient and frequently used equipment, and implementing dynamic crashtesting standards or evidence-based pull-tests values.

Newer generations of the patient compartment have not been shown to be safer $(4,23)$ and there is a knowledge gap in the behavior of its equipment and occupants during collisions. Crash-testing scenarios have assumed that occupants were restrained, however, current ambulance designs did not facilitate seat belt use in practice $(21,23)$.

Study Implications

This scoping review provides summarized information and a comprehensive reference list that procurement personnel and manufacturers can consider when writing request for proposals or designing ambulances and EMS equipment, respectively. However, there are still barriers for these knowledge users to access this literature, and to interpret and apply it accurately $(16,51)$.

Perhaps more importantly, this scoping review provides the scientific-basis needed to inform the development of future ambulance and EMS equipment standards. As mentioned, current standards, such as the KKK-1822F used in the US, lacked scientific-basis and considerations for safety and HFE $(20,21)$. Integrating HFE principles and research into design standards would enable designers to meet core HFE principles during product development and reduce the need to rely on their knowledge or desire to review scientific papers in HFE. As stated in several HFE textbooks (52-54), “...whereas many organizations pay little regard to research findings, few can afford to ignore standards." 
Future Studies

Despite the value of applying HFE principles into design standards, few studies have been designed or written in a manner that can provide grounded design requirements or recommendations. Standards set the minimum requirements for specifications, as well as technical and performance tests. As such, in order to ensure that future ambulances and EMS equipment function within the end-user's mental and physical capacity (training, anthropometry, fitness), future studies should strive to better understand the EMS population as it relates to design. In addition, future studies should aim to better understand the job demands of EMS (patient care, transport, handling) and its physical and social environments (weather, terrain, work culture) as it relates to design to ensure that the equipment will perform reliably under various real-life scenarios. Studies describing the EMS population, job demands and work environment are available, however the findings are not linked to setting dimensions, thresholds limits, or performance requirements.

Some manufacturers may take it upon themselves to interpret and apply relevant research data to their product designs. However, an inaccurate interpretation of the data or an incomplete understanding of the work system may lead to unexpected consequences. Conversely, the successful application of research may lead to new 'premium' products, unaffordable to many EMS services. Thus, interpreting research findings as itthey applyies to product design, or specifically undertaking studies that directly inform minimum design requirements may help to ensure the accurate application of research findings and potentially raise the bar for all end-users. 


\section{Limitations}

This scoping review uses a transparent and systematic approach to synthesize and extract the available literature on HFE interventions for patient compartments and EMS equipment; however, there are a couple limitations to be aware of. First, the number of articles found in 'Stage 1: define and understand the problem and its causes' of the 6SQUiD model may be underrepresented because factors unrelated to equipment design, such as shiftwork and traumatic incidents, were excluded from the search strategy. Second, due to the broad range of methods and HFE interventions, a formal quality appraisal of each study was not conducted. However, all studies were verified to be from peer reviewed journals.

\section{Conclusion \\ Earlier research, within the past 15 years, have has provided the foundational} knowledge of the complexities and HFE hazards associated with EMS work to help guide the development and implementation of impactful interventions, such as the powered cot. The field implementation of powered cots has significantly reduced stretcher-related injuries; however, a silver bullet solution cannot eliminate the core hazards of providing patient care during transport. This requires redesigning the workspace and workflow at a systems level. Embedding related scientific HFE research findings into ambulance and EMS equipment standards will lead to improving health, safety, and wellbeing of EMS personnel, as well as enhancing efficiency, productivity, and patient safety. 


\section{References}

1. Maguire BJ, Hunting KL, Smith GS, Levick NR. Occupational fatalities in emergency medical services: A hidden crisis. Ann Emerg Med. 2002;40(6):625-32.

2. Maguire BJ, Smith S. Injuries and fatalities among emergency medical technicians and paramedics in the United States. Prehosp Disaster Med. 2013;28(4):376-82.

3. Roberts $\mathrm{MH}$, Sim MR, Black O, Smith P. Occupational injury risk among ambulance officers and paramedics compared with other healthcare workers in Victoria, Australia: analysis of workers' compensation claims from 2003 to 2012. Occup Environ Med. 2015;72(7):489-95.

4. Slattery DE, Silver A. The Hazards of Providing Care in Emergency Vehicles: An Opportunity for Reform. Prehospital Emerg care. 2009;13(3):388-97.

5. Brice JH, Studnek JR, Bigham BL, Martin-Gill C, Custalow CB, Hawkins E, et al. EMS Provider and Patient Safety during Response and Transport: Proceedings of an Ambulance Safety Conference. Prehospital Emerg Care. 2012;16(1):3-19.

6. Maguire BJ, Smith S. Injuries and fatalities among emergency medical technicians and paramedics in the United States. Prehosp Disaster Med. 2013;28(4):376-82.

7. Maguire BJ, O’Meara PF, Brightwell RF, O’Neill BJ, Fitzgerald GJ. Occupational injury risk among Australian paramedics: an analysis of national data. Med J Aust. 2014;200(8):47780.

8. Gilad I, Byran E. Ergonomic evaluation of the ambulance interior to reduce paramedic discomfort and posture stress. Hum Factors. 2007;49(6):1019-32.

9. Byran E, Gilad I. Design considerations to inhance the safety of patient compartments in 
ambulance transporters. Int J Occup Saf Ergon. 2012;18(2):221-31.

10. Prairie J, Plamondon A, Hegg-Deloye S, Larouche D, Corbeil P. Biomechanical risk assessment during field loading of hydraulic stretchers into ambulances. Int J Ind Ergon. 2016;54:1-9.

11. Lavender SA, Conrad KM, Reichelt PA, T. Meyer F, Johnson PW. Postural analysis of paramedics simulating frequently performed strenuous work tasks. Appl Ergon. 2000;31(1):45-57.

12. Kibira D, Lee YT, Marshall J, Feeney AB, Avery L, Jacobs A. Simulation-based design concept evaluation for ambulance patient compartments. Simulation. 2015;91(8):691714.

13. Lavender SA, Conrad KM, Reichelt PA, T. Meyer F, Johnson PW. Biomechanical analyses of paramedics simulating frequently performed strenuous work task. Appl Ergon. 2000;31(1):167-77.

14. Maguire BJ, Hunting KL, Guidotti TL, Smith GS. Occupational Injuries among Emergency Medical Services Personnel. Prehospital Emerg Care [Internet]. 2005;9(4):405-11.

15. Armstrong TJ, Burdorf A, Descatha A, Farioli A, Graf M, Horie S, et al. Scientific basis of ISO standards on biomechanical risk factors. Scand J Work Environ Health. 2018.

16. Pinder AD. Literature review: Barriers to the application of Ergonomics/Human Factors in engineering design. Harpur Hill; 2015. Available from: http://www.hse.gov.uk/research/rrpdf/rr1006.pdf

17. Arksey H, O’Malley L. Scoping studies: towards a methodological framework. Int J Soc Res Methodol [Internet]. 2005;8(1):19-32. 
18. Levac D, Colquhoun $\mathrm{H}, \mathrm{O}^{\prime}$ Brien KK. Scoping studies: advancing the methodology. Implement Sci. 2010;5(1):69.

19. Wight D, Wimbush E, Jepson R, Doi L. Six steps in quality intervention development (6SQuID). J Epidemiol Community Health. 2015;70(5):520-5.

20. Dadfarnia $M$, Tina Lee $Y$, Kibira $D$, Feeney $A B$. Requirements analysis for safer ambulance patient compartments. Procedia Comput Sci. Elsevier B.V.; 2013;16:601-10.

21. Lee YT, Kibira D, Feeney AB, Marshall J. Ambulance Design Survey 2011: A Summary Report. J Res Natl Inst Stand Technol. 2013;118:381-95.

22. Hignett $S$, Crumpton E, Coleman R. Designing emergency ambulances for the 21 st century. Emerg Med J. 2009;26:135-40.

23. Reuter E, Camba JD. Understanding emergency workers' behavior and perspectives on design and safety in the workplace. Appl Ergon. 2017;59:73-83.

24. Cooper G, Ghassemieh E. Risk assessment of patient handling with ambulance stretcher systems (ramp/(winch), easi-loader, tail-lift) using biomechanical failure criteria. Med Eng Phys. 2007;29(7):775-87.

25. Jones A, Hignett S. Safe access/egress systems for emergency ambulances. Emerg Med J. $2007 ; 24(3): 200-5$.

26. Armstrong DP, Ferron R, Taylor C, McLeod B, Fletcher S, MacPhee RS, et al. Implementing powered stretcher and load systems was a cost effective intervention to reduce the incidence rates of stretcher related injuries in a paramedic service. Appl Ergon. 2017;62:34-42.

27. Studnek JR, Crawford J Mac, Fernandez AR. Evaluation of occupational injuries in an 
urban emergency medical services system before and after implementation of electrically powered stretchers. Appl Ergon. 2012;43(1):198-202.

28. Sommerich CM, Lavender SA, Radin Umar RZ, Li J, Park S, Dutt M. A biomechanical and subjective comparison of two powered ambulance cots. Ergonomics. 2015;58(11):188596.

29. Sommerich CM, Lavender SA, Radin Umar RZ, Le P, Mehta J, Ko P-L, et al. A biomechanical and subjective assessment and comparison of three ambulance cot design configurations. Ergonomics. 2012;55(11):1350-61.

30. Kluth K, Strasser H. Ergonomics in the rescue service - Ergonomic evaluation of ambulance cots. Int J Ind Ergon. 2006;36(3):247-56.

31. Lavender SA, Conrad KM, Reichelt PA, Gacki-Smith J, Kohok AK. Designing ergonomic interventions for EMS workers, Part I: Transporting patients down the stairs. Appl Ergon. 2007;38(1):71-81.

32. Karlsson KJ, Niemelä PH, Jonsson AR, Törnhage CJA. Using Shoulder Straps Decreases Heart Rate Variability and Salivary Cortisol Concentration in Swedish Ambulance Personnel. Saf Health Work. 2016;7(1):32-7.

33. Ballesteros T, Arana I, Pérez Ezcurdia A, Alfaro JR. Development and tests of a paediatric and neonatal immobilizer for ambulance transfers. J Med Eng Technol. 2014;38(4):20210.

34. Johnson DR, Hauswald M, Stockhoff C. Comparison of a vacuum splint device to a rigid backboard for spinal immobilization. Am J Emerg Med. 1996;14(4):369-72.

35. Conrad KM, Reichelt PA, Lavender SA, Gacki-Smith J, Hattle S. Designing ergonomic 
interventions for EMS workers: Concept generation of patient-handling devices. Appl Ergon. 2008;39(6):792-802.

36. Lavender SA, Conrad KM, Reichelt PA, Kohok AK, Gacki-Smith J. Designing ergonomic interventions for EMS workers-part II: Lateral transfers. Appl Ergon. 2007;38(2):227-36.

37. Weiler MR, Lavender SA, Crawford JM, Reichelt PA, Conrad KM, Browne MW. Identification of factors that affect the adoption of an ergonomic intervention among Emergency Medical Service workers. Ergonomics. 2012;55:1362-72.

38. Lavender SA, Conrad KM, Reichelt PA, Kohok AK, Gacki-Smith J. Designing ergonomic interventions for emergency medical services workers-part III: Bed to stairchair transfers. Appl Ergon. 2007;38(5):581-9.

39. Demmons LL. Chasing ambulance safety. Air Med J. 2005;24(3):112-6.

40. Sanddal ND, Albert S, Hansen JD, Kupas DF. Contributing Factors andlssues Associated with Rural Ambulance Crashes: Literature Review andAnnotated Bibliography. Prehospital Emerg Care. 2008;12(2):257-67.

41. Fournier M, Chenaitia H, Masson C, Michelet P, Behr M, Auffray J-P. Crew and Patient Safety in Ambulances: Results of a Personnel Survey and Experimental Side Impact Crash Test. Prehosp Disaster Med. 2013;28(04):370-5.

42. Larmon B, LeGassick TF, Schriger DL. Differential front and back seat safety belt use by prehospital care providers. Am J Emerg Med. 1993;11(6):595-9.

43. Johnson TD, Lindholm D, Dowd MD. Child and Provider Restraints in Ambulances: Knowledge, Opinions, and Behaviors of Emergency Medical Services Providers. Acad Emerg Med. 2006;13(8):886-92. 
44. Green JD, Yannaccone JR, Current RS, Sicher L a., Moore PH, Whitman GR. Assessing the performance of various restraints on ambulance patient compartment workers during crash events. Int J Crashworthiness. 2010;15:517-41.

45. Cho YS, Kim GW, Kim GY, Lee JH. Effect of safety belts on chest compression quality in a moving ambulance. Hong Kong J Emerg Med. 2015;22(3):145-53.

46. O'Neil J, Bull MJ, Sobus K. Issues and approaches to safely transporting children with special healthcare needs. J Pediatr Rehabil Med. 2011;4(4):279-88.

47. Kupas DF, Shayhorn M a., Green P, Payton TF. Structured Inspection of Medications Carried and Stored by Emergency Medical Services Agencies Identifies Practices That May Lead to Medication Errors. Prehospital Emerg Care. 2012;16(1):67-75.

48. Utku S, Özcanhan MH, Suleyman M. Automated personnel-assets-consumables-drug tracking in ambulance services for more effective and efficient medical emergency interventions. Comput Methods Programs Biomed. 2016;127:216-31.

49. Stevens AD, Hernandez C, Jones S, Moreira ME, Blumen JR, Hopkins E, et al. Color-coded prefilled medication syringes decrease time to delivery and dosing errors in simulated prehospital pediatric resuscitations: A randomized crossover trial. Resuscitation. 2015;96:85-91.

50. Lad U, Oomen NMCW, Callaghan JP, Fischer SL. Comparing the biomechanical and psychophysical demands imposed on paramedics when using manual and powered stretchers. Appl Ergon. 2018;70:167-74.

51. Yazdani A, Wells R. Barriers for implementation of successful change to prevent musculoskeletal disorders and how to systematically address them. Appl Ergon. 
2018;73:122-40.

52. Gray M, Stewart T. Standards in Ergonomics Design and Evaluation. In: Wilson JR, Sharples S, editors. Evaluation of Human Work. 4th ed. Boca Raton: CRC Press; 2015. p. 957-74.

53. Stewart T, Travis D. Guidelines, Standards, and Style Guides. In: The Human-Computer Interaction Handbook: Fundamentals, Evolving Technologie. Mahwah: Lawrence Erlbaum Associates; 2003. p. 991-1005.

54. Stewart T. Standards and Style Guides. In: The Politics of Usability: A Practical Guide to Designing Usable Systems in Industry. London: Springer London; 1998. p. 157-68. 


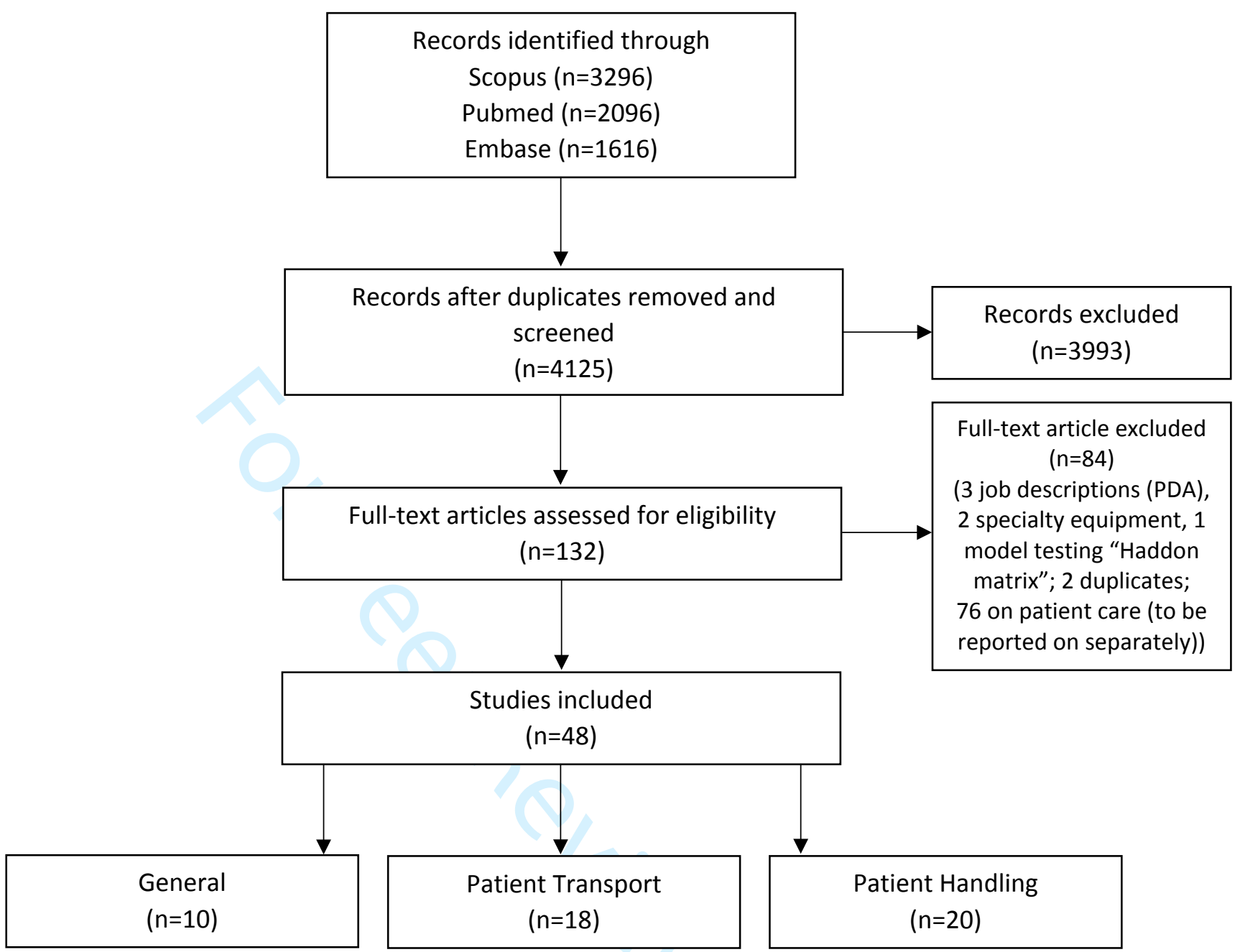

Figure 1: Flow diagram to demonstrate the process of retrieving relevant articles 


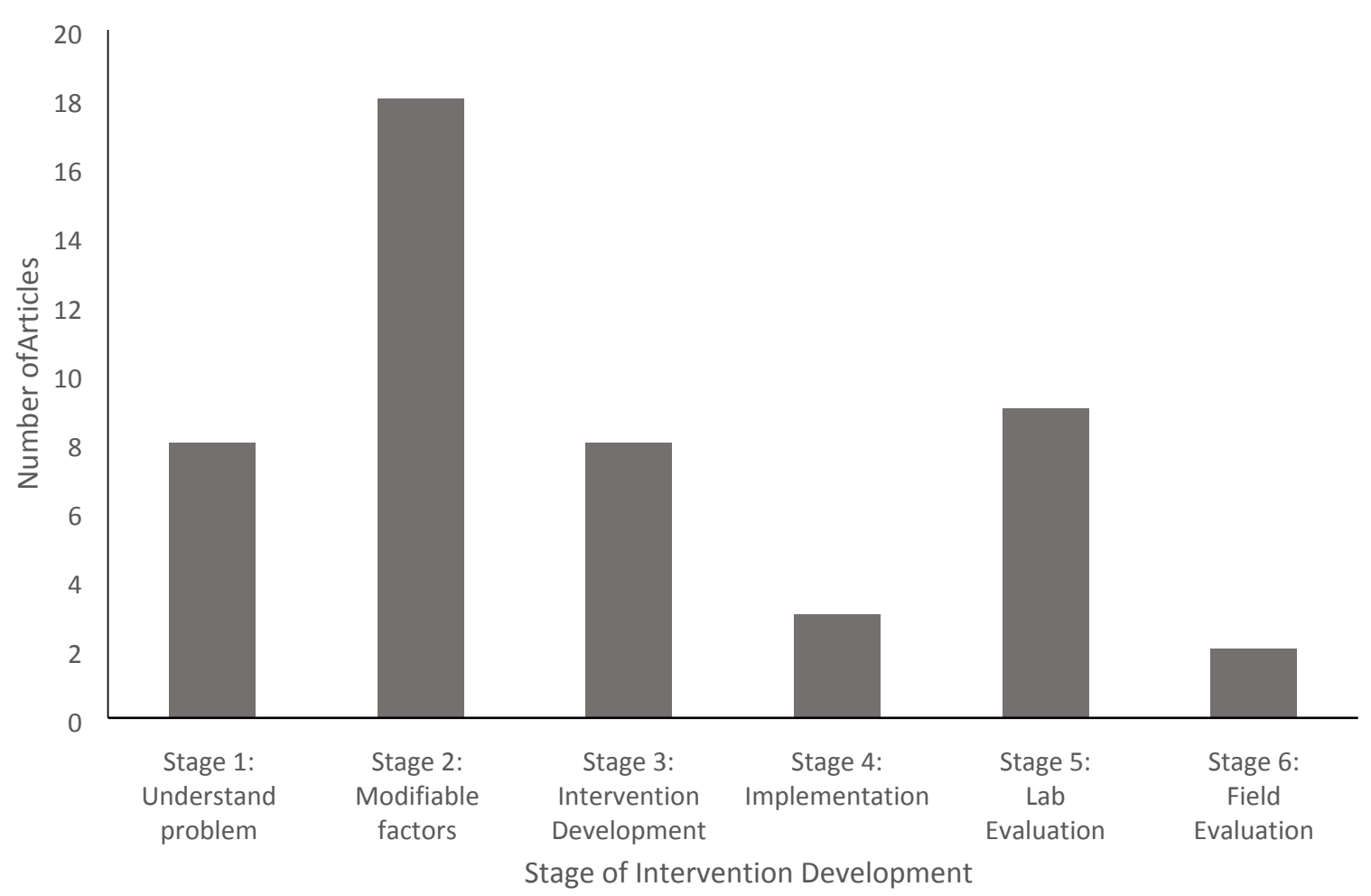

Figure 2: Amount of studies completed per stage of 6SQuID model. 
Table 1: Studies related to general design $(n=10)$.

\begin{tabular}{|c|c|c|c|c|c|}
\hline $\begin{array}{l}1^{\text {st }} \text { author } \\
\text { (Year) }\end{array}$ & 6SQuID & Study design & Study Population & Study Purpose & Study Rationale \\
\hline Snook (1972) & 2 & Qualitative description & N/A & $\begin{array}{l}\text { Describe factors such as heating, lighting, sound } \\
\text { insulation, identification, and vehicle motion with } \\
\text { reference to the treatment, comfort, or condition } \\
\text { of the patient. }\end{array}$ & $\begin{array}{l}\text { Inadequacies of many vehicles currently in use as ambulances } \\
\text { have been shown to work against the interests of the patient } \\
\text { requiring life support treatment, and it is suggested that this } \\
\text { warrants urgent attention and action. }\end{array}$ \\
\hline $\begin{array}{l}\text { Hignett } \\
(2009)\end{array}$ & 3 & Mixed methods & $\begin{array}{c}91 \text { Multiple- } \\
\text { stakeholder: } \\
\text { Strategic, } \\
\text { operational, } \\
\text { manufacturing } \\
\text { personnel } \\
\end{array}$ & $\begin{array}{l}\text { Investigate the short and long-term requirements } \\
\text { of emergency ambulances and equipment that will } \\
\text { be needed in the future in the UK Ambulance } \\
\text { Service. }\end{array}$ & $\begin{array}{l}\text { Before 2006, most NHS ambulance trusts produced their own } \\
\text { vehicle specification, resulting in over } 40 \text { different designs of } \\
\text { emergency ambulances in the UK. It has been noted that a lack } \\
\text { of standardization could introduce delays in treatment } \\
\text { provision. }\end{array}$ \\
\hline $\begin{array}{l}\text { Feufel } \\
(2009)\end{array}$ & 1 & Qualitative description & $\begin{array}{l}60 \text { hours of } \\
\text { convenience } \\
\text { sampling } \\
\text { Paramedics }\end{array}$ & $\begin{array}{l}\text { Report observations and highlight key areas where } \\
\text { HFE interventions may help improve the quality of } \\
\text { EMS systems and make the lives of paramedics } \\
\text { and their patients safer and easier. }\end{array}$ & $\begin{array}{l}\text { Emergencies are characterized by task complexity, changing } \\
\text { demands, and time pressure. Given the complexities involved } \\
\text { in EMS, it is surprising that only recently have US HFE } \\
\text { professionals begun to address potential issues in patient } \\
\text { safety. Occupational health and communication issues related } \\
\text { to EMS have been addressed mainly in European health } \\
\text { systems. }\end{array}$ \\
\hline $\begin{array}{l}\text { Slattery } \\
(2009)\end{array}$ & 2 & Narrative review & N/A & $\begin{array}{l}\text { 1) Raise awareness in the EMS community by } \\
\text { examining the various risk factors that contribute } \\
\text { to vehicular EMS injuries and fatalities. } \\
\text { 2) Outline the practical strategies for mitigating } \\
\text { these risks to EMS professionals. }\end{array}$ & $\begin{array}{l}\text { The risk of occupational death is disproportionately high for } \\
\text { EMS and the majority of incidents can be attributed to } \\
\text { transportation incidents. }\end{array}$ \\
\hline $\begin{array}{l}\text { Hignett } \\
(2011)\end{array}$ & 3 & Mixed methods & $\begin{array}{l}213 \text { Multiple- } \\
\text { stakeholder: } \\
\text { ambulance trusts } \\
\text { primary care and } \\
\text { acute trusts }\end{array}$ & $\begin{array}{l}\text { 1) Understand and identify current and future care } \\
\text { activities in emergency departments, minor injury } \\
\text { units, ambulances and out-of-hours general } \\
\text { practitioner services that could be delivered in the } \\
\text { community. } \\
\text { 2) Develop design specifications for portable } \\
\text { technologies. }\end{array}$ & $\begin{array}{l}\text { Organization of urgent and unscheduled care services need to } \\
\text { improve to address the fragmentation of care services including } \\
\text { duplication of provision, wasted resources and unnecessary } \\
\text { handoffs between providers. }\end{array}$ \\
\hline $\begin{array}{l}\text { Brice } \\
(2012)\end{array}$ & 2 & Qualitative description & 20 EMS Experts & $\begin{array}{l}\text { 1) Outline the nature hazards in the pre-hospital } \\
\text { environment. } \\
\text { 2) Propose a plan of action to address the safety } \\
\text { issues identified in the literature and expert } \\
\text { opinion at the conference. }\end{array}$ & $\begin{array}{l}\text { When human resources are stressed or limited and } \\
\text { environmental circumstances are dynamic and unpredictable, it } \\
\text { is difficult for providers to execute perfect decisions } \\
\text { consistently. An ambulance is a difficult working environment } \\
\text { fraught with hazards to both patients and providers. }\end{array}$ \\
\hline $\begin{array}{l}\text { Dadfarnia } \\
\text { (2013) }\end{array}$ & 2 & Mixed methods & N/A & $\begin{array}{l}\text { Identify needs and requirements of future patient } \\
\text { compartment design through structured and } \\
\text { systematic approaches. }\end{array}$ & $\begin{array}{l}\text { There are no science-based standards that govern ambulance } \\
\text { patient compartment design and safety. }\end{array}$ \\
\hline
\end{tabular}


Table 1 continued...

\begin{tabular}{|c|c|c|c|c|c|}
\hline $\begin{array}{c}1^{\text {st }} \text { author } \\
\text { (Year) }\end{array}$ & 6SQuID & Study design & Study Population & Study Purpose & Study Rationale \\
\hline $\begin{array}{l}\text { Lee } \\
(2013)\end{array}$ & 2 & Cross-sectional & $\begin{array}{c}2537 \text { EMTs, } \\
\text { paramedics, } \\
\text { emergency service } \\
\text { organizations }\end{array}$ & $\begin{array}{l}\text { Present an analysis of practitioners' concerns, } \\
\text { needs, and requirements for improved designs } \\
\text { elicited through the web-based survey of } \\
\text { ambulance design, held by the National } \\
\text { Institute of Standards and Technology. }\end{array}$ & $\begin{array}{l}\text { Design, construction, and performance standards that would } \\
\text { provide a baseline for improving safety, ergonomics and } \\
\text { emergency medical care are currently lacking in the US. }\end{array}$ \\
\hline $\begin{array}{l}\text { Casey } \\
\text { (2015) }\end{array}$ & 2 & Case report & 1 Ambulance driver & $\begin{array}{l}\text { Detail a case of Ebola in an ambulance driver } \\
\text { that may have resulted from body fluid } \\
\text { exposure that passed from the patient } \\
\text { compartment around the separating wall into } \\
\text { the driver cabin. }\end{array}$ & $\begin{array}{l}\text { While US and European standards all provide some level of detail } \\
\text { on the design of the ambulance, there are no requirements for the } \\
\text { wall between the patient compartment and driver cabin to be } \\
\text { waterproof. The only testing that is required is an external wash } \\
\text { test to assure that ambulances are waterproof from the outside. }\end{array}$ \\
\hline $\begin{array}{l}\text { Reuter } \\
\text { (2017) }\end{array}$ & 2 & Mixed methods & $\begin{array}{l}12 \text { in task analysis; } \\
103 \text { in survey } \\
\text { Paramedics }\end{array}$ & $\begin{array}{l}\text { Identify important threats to EMS workers, } \\
\text { both in fresh observation and to confirm or } \\
\text { contradict the findings of similar studies, in a } \\
\text { way that can be generalized and applied to a } \\
\text { designed solution. }\end{array}$ & $\begin{array}{l}\text { There lacks a hierarchy of which of these crucial issues needs to be } \\
\text { addressed the most, whether it be physical or mental, or whether } \\
\text { these risks manifest from the environment or from the nature of } \\
\text { the tasks. These identifiers are needed in order to develop } \\
\text { interventions that effectively improve EMS worker conditions. }\end{array}$ \\
\hline
\end{tabular}


Table 2: Patient handling studies $(n=20)$.

\begin{tabular}{|c|c|c|c|c|c|c|}
\hline $\begin{array}{l}1^{\text {st }} \text { author } \\
\text { (Year) }\end{array}$ & 6SQuID & Study Design & Study Population & Study Purpose & $\begin{array}{c}\text { Control (O) } \\
\text { Intervention (X) }\end{array}$ & Dependent Variables \\
\hline \multicolumn{7}{|c|}{ Loading Systems } \\
\hline $\begin{array}{l}\text { Cooper } \\
(2007)\end{array}$ & 1 & Cross-over & 12 paramedics & $\begin{array}{l}\text { Analyze the loads applied by ambulance workers using } 3 \text { different } \\
\text { stretcher loading systems (ramp, easi-loader and tail-lift) to } \\
\text { load/unload the ambulance. }\end{array}$ & & $\begin{array}{l}\text { H: Lifting, carrying and push/pull forces, spinal } \\
\text { loading }\end{array}$ \\
\hline $\begin{array}{l}\text { Jones } \\
(2007)\end{array}$ & 1 & Mixed methods & $\begin{array}{l}134 \text { paramedics \& } \\
\text { manufacturers; } 3 \\
\text { EMS agencies; } 378 \\
\text { hours of data }\end{array}$ & $\begin{array}{l}\text { Evaluate the three most widely used ambulance stretcher loading } \\
\text { systems: easi-loader, ramp/winch and tail lift to identify a preferred } \\
\text { system based on safety and usability. }\end{array}$ & & $\begin{array}{l}\text { H: Postural REBA assessment } \\
\text { P: Hierarchical task analysis } \\
\text { A: Ranking of important factors, significant/critical } \\
\text { incidents, design issues }\end{array}$ \\
\hline \multicolumn{7}{|l|}{ Cots } \\
\hline $\begin{array}{l}\text { Kluth, } \\
(2005)\end{array}$ & 1 & Cross-over & $\begin{array}{l}12 \text { paramedics \& } \\
\text { firefighters }\end{array}$ & $\begin{array}{l}\text { Compare } 3 \text { different types of cots in terms of ergonomic quality } \\
\text { when performing carrying, lifting, and loading/unloading tasks. }\end{array}$ & & $\begin{array}{l}\text { H: Muscle activity, heart rate } \\
\text { A: Subjective evaluation }\end{array}$ \\
\hline $\begin{array}{l}\text { Sommerich } \\
\text { (2012) }\end{array}$ & 1 & Cross-over & 15 paramedics & $\begin{array}{l}\text { Examine the effects of ambulance cot design, specifically the leg } \\
\text { folding mechanism and handle design and location, on the physical } \\
\text { stresses imposed on EMS workers when they perform } 3 \text { common, } \\
\text { physically demanding tasks. }\end{array}$ & & $\begin{array}{l}\text { H: Muscle activity } \\
\text { P: Task style and duration } \\
\text { A: Rating of perceived exertion, preference ratings }\end{array}$ \\
\hline $\begin{array}{l}\text { Goodloe } \\
\text { (2012) }\end{array}$ & 1 & $\begin{array}{l}\text { Retrospective } \\
\text { cohort }\end{array}$ & $\begin{array}{l}1 \text { EMS agency: } \\
23 \text { stretcher- } \\
\text { related adverse } \\
\text { events }\end{array}$ & $\begin{array}{l}\text { Analyze the types and frequencies of injuries sustained by patients } \\
\text { and EMS professionals directly related to manual stretcher } \\
\text { operations occurring in a large, urban EMS system in the } \\
\text { southwestern United States. }\end{array}$ & & $\begin{array}{l}\text { S: Stretcher-related injuries, nature of the event, } \\
\text { contributing factors, timing of the incident } \\
\text { P: Stretcher-related injuries, patient behaviour }\end{array}$ \\
\hline $\begin{array}{l}\text { Studneck } \\
\text { (2012) }\end{array}$ & 6 & $\begin{array}{l}\text { Retrospective } \\
\text { cohort }\end{array}$ & $\begin{array}{l}1 \text { EMS agency; } \\
1478 \text { injuries }\end{array}$ & $\begin{array}{l}\text { Evaluate occupational injuries in an urban EMS system before and } \\
\text { after the implementation of hydraulic stretchers. }\end{array}$ & $\begin{array}{l}\text { O: Conventional stretcher } \\
\text { X: Powered stretcher }\end{array}$ & $\begin{array}{l}\text { S: Injury incidence rates, lost time injuries, lost } \\
\text { work days, lost-day rate, injuries with lost-time } \\
\text { rate }\end{array}$ \\
\hline $\begin{array}{l}\text { Sommerich } \\
\text { (2015) }\end{array}$ & 5 & Cross-over & 16 paramedics & $\begin{array}{l}\text { Systematically examine the effect of ambulance cot design, } \\
\text { specifically the different leg folding mechanisms of two powered } \\
\text { cots, on the physical stresses imposed on EMS workers when they } \\
\text { perform two common lifting tasks. }\end{array}$ & & $\begin{array}{l}\text { H: Muscle activity, ground reaction forces } \\
\text { P: Task duration } \\
\text { A: Perceived exertion, opinions on usability, } \\
\text { preference and design features }\end{array}$ \\
\hline $\begin{array}{l}\text { Prairie } \\
(2016)\end{array}$ & 2 & $\begin{array}{l}\text { Quantitative } \\
\text { descriptive }\end{array}$ & 58 paramedics & $\begin{array}{l}\text { 1) Assess compression and shear forces at } L 5 / S 1 \text { and the risk of } \\
\text { injury while loading a hydraulic stretcher into an ambulance. } \\
\text { 2) Determine the main variables that have a significant effect on } \\
\text { compression and shear forces during real-life stretcher loading. }\end{array}$ & & $\begin{array}{l}\text { H: Spinal loading, hand forces, posture } \\
\text { P: Task duration }\end{array}$ \\
\hline $\begin{array}{l}\text { Armstrong } \\
\text { (2017) }\end{array}$ & 6 & $\begin{array}{l}\text { Retrospective } \\
\text { cohort }\end{array}$ & 2 EMS agencies & $\begin{array}{l}\text { Compare injury incidence rates, days lost, and compensation costs } \\
\text { between } 2 \text { EMS before and after the implementation of powered } \\
\text { stretchers and load systems, and to estimate the economic } \\
\text { feasibility of such an intervention. }\end{array}$ & $\begin{array}{l}\text { O: Conventional stretcher } \\
\text { X: Powered stretcher and } \\
\text { loader system }\end{array}$ & $\begin{array}{l}\text { S: Injury incidence rates, days lost, incident } \\
\text { classification, stretcher-related injuries, injury } \\
\text { incidents per call, lost time incidents per MSD, lost } \\
\text { time + health care incidents per MSD } \\
\text { A: Compensation costs }\end{array}$ \\
\hline
\end{tabular}


Table 2 continued...

Backboards

\begin{tabular}{|c|c|c|c|c|c|c|}
\hline $\begin{array}{l}\text { Ballesteros } \\
\text { (2014) }\end{array}$ & 3 & $\begin{array}{l}\text { Equipment } \\
\text { development and } \\
\text { description }\end{array}$ & $\begin{array}{l}\text { Mannequin } \\
\text { simulating }\end{array}$ & Develop and test a paediatric immobilizer. & & $\begin{array}{l}\text { P: Radio-transparency, cleanability, resistance to } \\
\text { disinfectants, alcohol, hydrogen peroxide and } \\
\text { iodine, floatability, boat transport test } \\
\text { A: Ability to fit different sizes and pathologies }\end{array}$ \\
\hline $\begin{array}{l}\text { Johnson } \\
\text { (1996) }\end{array}$ & 5 & Controlled trial & $\begin{array}{l}60 \text { paramedics and } \\
\text { paramedic } \\
\text { students }\end{array}$ & $\begin{array}{l}\text { Compare a vacuum splint device to a rigid wooden backboard in } \\
\text { terms of patient comfort, speed of application and degree of } \\
\text { immobilization. }\end{array}$ & $\begin{array}{l}\text { O: Traditional wooden } \\
\text { backboard } \\
\text { X: Vacuum splint }\end{array}$ & $\begin{array}{l}\text { P: Speed of application, level of immobilization } \\
\text { A: Patient comfort }\end{array}$ \\
\hline \multicolumn{7}{|c|}{ Patient Transfer Accessorises } \\
\hline $\begin{array}{l}\text { Lavender } \\
\text { (2007b) }\end{array}$ & 5 & Controlled trial & $\begin{array}{l}22 \text { firefighter } \\
\text { paramedics }\end{array}$ & $\begin{array}{l}\text { Evaluate ergonomic interventions aimed at reducing biomechanical } \\
\text { loads on the back as patients are laterally transferred from a bed to } \\
\text { a stretcher or from a stretcher to a hospital gurney. }\end{array}$ & $\begin{array}{l}\text { O: Standard bedsheet } \\
\text { transfer } \\
\text { X: Bridgeboard, dual rod, } \\
\text { single rod, dual rod \& } \\
\text { bridgeboard, single rod \& } \\
\text { bridgeboard }\end{array}$ & $\begin{array}{l}\text { H: Muscular activity, spine kinematics, peak 3D } \\
\text { motions } \\
\text { A: Perceived exertion }\end{array}$ \\
\hline $\begin{array}{l}\text { Weiler } \\
\text { (2012) }\end{array}$ & 4 & Prospective & 190 paramedics & $\begin{array}{l}\text { 1) Identify key factors from a large set of sampled measures related } \\
\text { to transfer-board use; } \\
\text { 2) Identify the factors that predict EMS workers' intention to use the } \\
\text { transfer-board intervention; } \\
\text { 3) Identify the factors that predict the adoption of the transfer- } \\
\text { board as measured through actual use. }\end{array}$ & & $\begin{array}{l}\text { A: Support of innovations, ease of use, relative } \\
\text { advantage, task-technology compatibility, } \\
\text { perceived adequacy of training, voluntariness, } \\
\text { partner support, endorsement by champions, } \\
\text { optimistic bias, attitude towards use and } \\
\text { intentions to use }\end{array}$ \\
\hline $\begin{array}{l}\text { Weiler } \\
(2013)\end{array}$ & 4 & Prospective & 221 paramedics & $\begin{array}{l}\text { Develop a model to determine how the factors directly and } \\
\text { indirectly affect the adoption of the transfer-board intervention. }\end{array}$ & & \\
\hline $\begin{array}{l}\text { Karlsson } \\
(2016)\end{array}$ & 5 & Controlled trial & $\begin{array}{l}20 \text { paramedics \& } \\
\text { nurses }\end{array}$ & $\begin{array}{l}\text { Evaluate whether the use of shoulder straps decreases physical } \\
\text { effort in the form of decreased heart rate and cortisol } \\
\text { concentration. }\end{array}$ & $\begin{array}{l}\text { O: No shoulder straps } \\
\text { X: Shoulder straps }\end{array}$ & H: Heart rate, salivary cortisol \\
\hline $\begin{array}{l}\text { Lavender } \\
\text { (2007c) }\end{array}$ & 5 & Controlled trial & $\begin{array}{l}22 \text { firefighter } \\
\text { paramedics }\end{array}$ & $\begin{array}{l}\text { Evaluate ergonomic interventions aimed at reducing biomechanical } \\
\text { loads on the back as patients are transferred from the bed to a } \\
\text { stairchair. }\end{array}$ & $\begin{array}{l}\text { O: Under-axilla lift } \\
\text { X: Transfer slings }\end{array}$ & $\begin{array}{l}\text { H: Muscular activity, spine kinematics, spinal } \\
\text { loading } \\
\text { A: Perceived exertion }\end{array}$ \\
\hline \multicolumn{7}{|c|}{ Multiple Patient Handling equipment } \\
\hline $\begin{array}{l}\text { Lavender, } \\
\text { (2000a) }\end{array}$ & 1 & Cross-over & $\begin{array}{l}20 \text { firefighter } \\
\text { paramedics }\end{array}$ & $\begin{array}{l}\text { Biomechanically evaluate the data obtained during the task } \\
\text { simulation and analysis phase using two commonly applied models } \\
\text { for quantifying musculoskeletal loading and low back injury risk. }\end{array}$ & & $\begin{array}{l}\text { H: Back and shoulder strength, spinal loading, low } \\
\text { back disorder probability }\end{array}$ \\
\hline $\begin{array}{l}\text { Lavender, } \\
\text { (2000b) }\end{array}$ & 1 & Cross-over & $\begin{array}{l}20 \text { firefighter } \\
\text { paramedics }\end{array}$ & $\begin{array}{l}\text { Describe the tasks in terms of the roles played, the postures } \\
\text { assumed, and the exertions performed by trained FF/Ps while } \\
\text { completing the most frequently performed strenuous tasks. }\end{array}$ & & H: Body posture, hand forces \\
\hline $\begin{array}{l}\text { Lavender } \\
\text { (2007a) }\end{array}$ & 5 & Controlled trial & $\begin{array}{l}22 \text { firefighter } \\
\text { paramedics }\end{array}$ & $\begin{array}{l}\text { Evaluate ergonomic interventions aimed at reducing biomechanical } \\
\text { loads on the back as patients are transported down the stairs. }\end{array}$ & $\begin{array}{l}\text { O: Conventional stretcher, } \\
\text { stairchair and backboard } \\
\text { X: Footstrap, backboard } \\
\text { wheeler, decent control } \\
\text { system, extended handle } \\
\text { stair chair }\end{array}$ & $\begin{array}{l}\text { H: Muscular activity, trunk posture, heart rate } \\
\text { P: Task duration } \\
\text { A: Perceived exertion }\end{array}$ \\
\hline $\begin{array}{l}\text { Conrad, } \\
2008\end{array}$ & 3 & $\begin{array}{l}\text { Qualitative } \\
\text { descriptive }\end{array}$ & $\begin{array}{l}25 \text { firefighter } \\
\text { paramedics }\end{array}$ & $\begin{array}{l}\text { Generate ideas for the design of new EMS patient-handling devices } \\
\text { that are framed within the contextual reality of the end-user. }\end{array}$ & & $\begin{array}{l}\text { H: Movements and postures that increase risk of } \\
\text { injury } \\
\text { A: Affordability, portability, operability, } \\
\text { cleanability, durability. }\end{array}$ \\
\hline
\end{tabular}


Table 3: Patient transport studies ( $n=18)$.

\begin{tabular}{|c|c|c|c|c|c|}
\hline $\begin{array}{l}1^{\text {st }} \text { author, } \\
\text { Year }\end{array}$ & 6SQuID & Study Design & Study Sample & $\begin{array}{c}\text { Control (0) } \\
\text { Intervention }(\mathbf{X})\end{array}$ & Dependent Variables \\
\hline \multicolumn{6}{|c|}{ Space and Layout } \\
\hline $\begin{array}{l}\text { Ferreira } \\
(2005)\end{array}$ & 2 & Observational & 14 Paramedics & $\begin{array}{l}\text { Review the layout of one UK ambulance design with respect to clinical } \\
\text { efficiency and investigate the impact of the layout on the musculoskeletal } \\
\text { well-being of paramedics. }\end{array}$ & $\begin{array}{l}\text { H: Postural Analysis } \\
\text { P: Link Analysis }\end{array}$ \\
\hline $\begin{array}{l}\text { Gilad } \\
(2007)\end{array}$ & 3 & Observational & $\begin{array}{l}31 \text { EMS professionals } \\
\text { (paramedics, shift } \\
\text { managers, med docs) }\end{array}$ & $\begin{array}{l}\text { Produce feasible suggestions for an improved overall design of the patient } \\
\text { compartment to make the ambulance working cell ergonomically suitable } \\
\text { as a mobile working environment unit for use by the medical personnel } \\
\text { treating a patient during emergency runs. }\end{array}$ & $\begin{array}{l}\text { S: Seatbelt use } \\
\text { H: Posture Analysis } \\
\text { P: Work habits }\end{array}$ \\
\hline $\begin{array}{l}\text { Alejo } \\
\text { (2009) }\end{array}$ & 3 & Mix methods & SUMMA 112 & $\begin{array}{l}\text { Present the main results of a project intended to improve the design of the } \\
\text { patient care space of Intensive Care Units of the Medical Emergency } \\
\text { Services in the Madrid Region. }\end{array}$ & \\
\hline $\begin{array}{l}\text { Byran } \\
(2012)\end{array}$ & 3 & Simulation & $\begin{array}{l}31 \text { EMS members } \\
\text { (paramedics and docs) }\end{array}$ & $\begin{array}{l}\text { Provide a comprehensive functional and behavioral analysis, which may } \\
\text { lead to a safer layout design for ambulances. }\end{array}$ & \\
\hline $\begin{array}{l}\text { Kibira } \\
(2015)\end{array}$ & 3 & Simulation & N/A & $\begin{array}{l}\text { Present a simulation-based approach to improve patient compartment } \\
\text { designs to fulfill developed requirements for performance and safety. }\end{array}$ & $\begin{array}{l}\text { H: Lifting analysis and back strain and } \\
\text { analysis of upper limb disorders } \\
\text { P: 3DCAD Model }\end{array}$ \\
\hline $\begin{array}{l}\text { Deros } \\
(2016)\end{array}$ & 2 & Observational & 5 EMS personnel & $\begin{array}{l}\text { 1) Evaluate the ambulance dimensions and workstation design. } \\
\text { 2) Conduct a Rapid Entire Body Assessment (REBA) to examine ambulance's } \\
\text { EMS workers' activities and their associated MSDs risk factors. }\end{array}$ & $\begin{array}{l}\text { H: Observation of tasks, and analysis of } \\
\text { postures }\end{array}$ \\
\hline \multicolumn{6}{|c|}{ Crashworthiness } \\
\hline $\begin{array}{l}\text { Demmons } \\
(2005)\end{array}$ & 2 & Case study & N/A & $\begin{array}{l}\text { Raise awareness of the safety risks of ground transport, assist those doing } \\
\text { ground transport to assess their ambulances or determine what to look for } \\
\text { when buying/leasing a unit, and improve ground ambulance safety to } \\
\text { prevent injuries and death. }\end{array}$ & \\
\hline $\begin{array}{l}\text { Sanddal } \\
\text { (2008) }\end{array}$ & 2 & Literature review & 28 Articles & $\begin{array}{l}\text { Identify published literature that describes the frequency, epidemiology, } \\
\text { etiology, typology, and cost (i.e., human and fiscal) of ambulance crashes } \\
\text { generally, and rural ambulance crashes specifically. }\end{array}$ & \\
\hline $\begin{array}{l}\text { Fournier } \\
\text { (2013) }\end{array}$ & 2 & Mix methods & 108 EMS personnel & $\begin{array}{l}\text { 1) Assess by survey the French Emergency Medical Services (EMS) to } \\
\text { determine the layout of the vehicle most often used and the EMS } \\
\text { personnel's behavior during transport. } \\
\text { 2) Conduct a crash test to analyze the injuries which may affect EMS } \\
\text { personnel and patients in the rear patient compartment. }\end{array}$ & $\begin{array}{l}\text { S: Work habits in ambulance, crash } \\
\text { testing, observation of tasks } \\
\text { A: Surveyed about beliefs of design and } \\
\text { layout }\end{array}$ \\
\hline \multicolumn{6}{|l|}{ Restraints } \\
\hline $\begin{array}{l}\text { Larmon } \\
(1993)\end{array}$ & 2 & $\begin{array}{l}\text { Quantitative } \\
\text { descriptive }\end{array}$ & $\begin{array}{l}900 \\
\text { Prehospital care providers }\end{array}$ & $\begin{array}{l}\text { Assess the behavior of prehospital care personnel regarding safety belt use } \\
\text { in the front and rear compartment. }\end{array}$ & $\begin{array}{l}\text { S: Collision history, seatbelt usage } \\
\text { A: Beliefs about seatbelt use }\end{array}$ \\
\hline $\begin{array}{l}\text { Johnson } \\
\text { (2006) }\end{array}$ & 2 & $\begin{array}{l}\text { Quantitative } \\
\text { descriptive }\end{array}$ & $\begin{array}{l}302 \\
\text { EMS providers }\end{array}$ & $\begin{array}{l}\text { Measure the knowledge, opinions, and behaviours of EMS personnel } \\
\text { regarding child and provider restraint use in ambulances. }\end{array}$ & $\begin{array}{l}\text { S: Knowledge and behaviour about } \\
\text { restraints for passenger/occupant/self } \\
\text { A: opinions on safety }\end{array}$ \\
\hline $\begin{array}{l}\text { Green } \\
(2010)\end{array}$ & 5 & Controlled trial & N/A & $\begin{array}{l}\text { Determine if mobility restraints could improve emergency medical service } \\
\text { (EMS) worker safety by providing patient compartment occupants with a } \\
\text { higher level of protection than when unrestrained, while still allowing } \\
\text { mobility to care for patients. }\end{array}$ & $\begin{array}{l}\text { S: Standard injury analysis } \\
\text { H: Biomechanical analysis }\end{array}$ \\
\hline
\end{tabular}


Table 3 continued...

\begin{tabular}{|c|c|c|c|c|c|c|}
\hline $\begin{array}{l}\text { O’Neil } \\
(2011)\end{array}$ & 2 & Literature review & $\begin{array}{l}\text { Children with special } \\
\text { healthcare needs and } \\
\text { their care providers }\end{array}$ & $\begin{array}{l}\text { Discuss the basic principles of child passenger safety for CSHCN } \\
\text { and the use of child occupant restraint devices. }\end{array}$ & & \\
\hline $\begin{array}{l}\text { Cho } \\
(2015)\end{array}$ & 5 & $\begin{array}{l}\text { Randomized } \\
\text { control trial }\end{array}$ & 35 Public EMS & $\begin{array}{l}\text { Examine the effect of specially designed safety belts on standard } \\
\text { cardiopulmonary resuscitation (CPR) and determine whether } \\
\text { straddle (STR) CPR is equivalent to standard CPR in a moving } \\
\text { ambulance. }\end{array}$ & $\begin{array}{l}\text { O: No seat belt usage and } \\
\text { standard CPR } \\
\text { X: Specially designed safety } \\
\text { belt and straddle CPR }\end{array}$ & $\begin{array}{l}\text { P: Compression measures } \\
\text { A: Assessment of experience }\end{array}$ \\
\hline \multicolumn{7}{|l|}{ Storage } \\
\hline $\begin{array}{l}\text { Pearson } \\
(2003)\end{array}$ & $1+2$ & Literature review & $\mathrm{N} / \mathrm{A}$ & $\begin{array}{l}\text { Describe the role of the medical technician/paramedic and review } \\
2 \text { types of drug storage: the emergency department and } \\
\text { prehospital emergency medical services (EMS). }\end{array}$ & & \\
\hline $\begin{array}{l}\text { Kupas } \\
(2012)\end{array}$ & 2 & $\begin{array}{l}\text { Qualitative } \\
\text { descriptive }\end{array}$ & $\begin{array}{l}9 \text { Advanced life support } \\
\text { EMS agencies }\end{array}$ & $\begin{array}{l}\text { Provide a descriptive account of EMS practices related to carrying } \\
\text { and storing medications that have the potential for causing a } \\
\text { medication administration error or patient harm. }\end{array}$ & & \\
\hline $\begin{array}{l}\text { Stevens } \\
(2015)\end{array}$ & 5 & $\begin{array}{l}\text { Prospective } \\
\text { randomized, cross- } \\
\text { over study }\end{array}$ & 10 Paramedics & $\begin{array}{l}\text { Evaluate novel, prefilled medication syringes labeled with color- } \\
\text { coded volumes corresponding to the weight-based dosing of the } \\
\text { Broselow Tape, compared to conventional medication } \\
\text { administration, in simulated prehospital pediatric resuscitation } \\
\text { scenarios. }\end{array}$ & $\begin{array}{l}\text { O: Medication kits with } \\
\text { conventional ampoules } \\
\text { X: Prefilled, colour-coded } \\
\text { syringes }\end{array}$ & $\begin{array}{l}\text { P: Time to delivery and errors } \\
\text { A: Ease of use, beliefs, and confidence }\end{array}$ \\
\hline $\begin{array}{l}\text { Utku } \\
(2016)\end{array}$ & 4 & $\begin{array}{l}\text { Qualitative } \\
\text { descriptive }\end{array}$ & $\mathrm{N} / \mathrm{A}$ & $\begin{array}{l}\text { Present a complete solution (Effective and Efficient Ambulance } \\
\text { PACD Tracking System) based on a centralized database supported } \\
\text { by radio frequency identification and Bluetooth low energy } \\
\text { identification and tracking technologies. }\end{array}$ & & A: Unit prices \\
\hline
\end{tabular}

$\boldsymbol{X}=$ Intervention, $\mathbf{O}=$ control, $\boldsymbol{H}=$ Health, $\boldsymbol{S}=$ Safety, $\boldsymbol{P}=$ Performance, $\boldsymbol{A}=$ Adoption 


\section{HFE}

\section{EMBASE}

human engineering.mp. OR human factor.mp. OR human factors.mp. OR engineering control.mp. OR engineering controls.mp. OR user-centered design.mp. OR user-centered designs.mp. OR equipment design.mp. OR equipment designs.mp. OR ambulance design.mp. OR ambulance designs.mp. OR ergonomic*.mp. OR pre-intervention.mp. OR preintervention.mp. OR post-intervention.mp. OR postintervention.mp. OR intervention*.mp. OR workflow.mp. OR work flow.mp. OR work-flow.mp. OR layout*.mp. OR workspace.mp. OR workspaces.mp. OR anthropometric*.mp. OR safety.mp. OR safety/OR ergonomics/ OR equipment design/

\section{EMS personnel}

((emergency.mp. OR ambulance.mp. OR EMS.mp.) AND (rescuer*.mp. OR responder*.mp. OR worker*.mp. OR officer*.mp. OR personnel*.mp. OR technician*.mp. OR professional*.mp. OR operational staff OR provider*.mp.)) OR paramedic.mp. OR paramedics.mp. OR rescue personnel/

\section{Ambulance and EMS equipment}

((emergency.mp. OR EMS.mp.) AND (vehicle*.mp. OR transport*.mp. OR mobile unit*.mp.)) OR ambulance*.mp. OR patient compartment*.mp. OR equipment and supplies.mp. OR stretcher*.mp. OR cot.mp. OR cots.mp. OR backboard.mp. OR backboards.mp. OR wheel chair.mp. OR wheel chairs.mp. OR stair chair.mp. OR stair chairs.mp. OR storage.mp. OR cabinet.mp. OR cabinets.mp. OR drawer.mp. OR drawers.mp. OR label.mp. OR labelling.mp. OR labels.mp. OR handle.mp. OR handles.mp. OR handrail.mp. OR handrails.mp. OR first aid kit.mp. OR first aid kits.mp. OR grab bag.mp. OR grab bags.mp. OR medical bag.mp. OR medical bags.mp. OR airway bag.mp. OR airway bags.mp. OR sharps.mp. OR CPR.mp. OR cardiopulmonary resuscitation.mp. OR defibrillator*.mp. OR personal protective equipment.mp. OR belt*.mp. OR restraint*.mp. OR needles.mp. OR needle.mp. OR ambulance/ OR ambulance transportation/ OR cardiovascular equipment/ OR life support equipment/ OR protective equipment/ OR stretcher/OR storage/ 


\section{HFE}

\section{PubMed}

human engineering[tiab] OR human factor*[tiab] OR engineering control*[tiab] OR usercentered design*[tiab] OR equipment design*[tiab] OR ambulance design*[tiab] OR ergonomic*[tiab] OR pre-intervention[tiab] OR preintervention[tiab] OR post-intervention[tiab] OR postintervention[tiab] OR intervention*[tiab] OR work organization[tiab] OR workflow[tiab] OR work flow[tiab] OR work-flow[tiab] OR layout*[tiab] OR workspace* OR anthropometric*[tiab] OR safety[tiab] OR human engineering[MeSH] OR equipment design[MeSH] OR safety[MeSH:noexp] OR safety management[MeSH:noexp]

\section{EMS personnel}

((emergency[tiab] OR ambulance[tiab] OR EMS[tiab]) AND (rescuer*[tiab] OR responder*[tiab] OR worker*[tiab] OR officer*[tiab] OR personnel*[tiab] OR technician*[tiab] OR professional*[tiab] OR operational staff[tiab] OR provider*)) OR paramedic[tiab] OR paramedics[tiab] OR emergency medical technicians[MeSH]

\section{Ambulance and EMS Equipment}

((emergency[tiab] OR EMS[tiab]) AND (vehicle*[tiab] OR transport*[tiab] OR mobile unit*[tiab])) OR ambulance*[tiab] OR patient compartment*[tiab] OR equipment and supplies[tiab] OR stretcher*[tiab] OR cot[tiab] OR cots[tiab] OR backboard[tiab] OR backboards[tiab] OR gurney[tiab] OR gurneys[tiab] OR wheel chair*[tiab] OR stair chair*[tiab] OR storage*[tiab] OR cabinet*[tiab] OR drawer*[tiab] OR label*[tiab] OR handle*[tiab] OR handrai**[tiab] OR first aid kit[tiab] OR grab bag[tiab] OR medical bag[tiab] OR airway bag[tiab] OR sharps[tiab] OR needle* OR CPR[tiab] OR cardiopulmonary resuscitation[tiab] OR defibrillator*[tiab] OR personal protective equipment[tiab] OR belt*[tiab] OR restraint*[tiab] OR ambulances[mesh:noexp] OR equipment and supplies[mesh] 
HFE

\section{Scopus}

"human engineering" $O R$ "human factor" $O R$ "human factors" OR "engineering control" OR "engineering controls" OR "user-centered design" OR "user-centered designs" OR "equipment design" OR "equipment designs" OR "ambulance design" OR "ambulance designs" OR ergonomic* OR pre-intervention OR preintervention OR post-intervention OR postintervention OR intervention* OR "work organization" OR workflow OR "work flow" OR work-flow OR layout* OR workspace OR workspaces OR safety

\section{EMS personnel}

((emergency OR ambulance OR EMS) AND (rescuer* OR responder* OR worker* OR officer* OR personnel* OR technician* OR professional* OR "operational staff" OR provider*)) OR paramedic OR paramedics

\section{Ambulance EMS equipment}

((emergency OR EMS) AND (vehicle* OR transport* OR mobile unit*)) OR ambulance* OR "patient compartment" OR "patient compartments" OR "equipment and supplies" OR stretcher* OR cot OR cots OR backboard OR backboards OR gurney OR gurneys OR "wheel chair" OR "wheel chairs" OR "stair chair" OR "stair chairs" OR storage OR cabinet OR cabinets OR drawer OR drawers OR label OR labelling OR labels OR handle OR handles OR handrail OR handrails OR "first aid kit" OR "first aid kits" OR "grab bag" OR "grab bags" OR "medical bag" OR "medical bags" OR "airway bag" OR "airway bags" OR sharps OR needles OR needle OR CPR OR "cardiopulmonary resuscitation" OR defibrillator* OR "personal protective equipment" OR belt* OR restraint* 


\section{Preliminary screening tool}

\begin{tabular}{|c|c|c|c|c|c|}
\hline Screening Questions & \multicolumn{2}{|c|}{ Response Options } & & Action \\
\hline $\begin{array}{c}\text { 1. Are EMS personnel the focus of the } \\
\text { paper? }\end{array}$ & YES & NO & UNCLEAR & & If NO, exclude \\
\cline { 1 - 4 } $\begin{array}{c}\text { 2. Is the paper about: } \\
\text { a. the design of the patient } \\
\text { compartment and equipment } \\
\text { OR }\end{array}$ & YES & NO & UNCLEAR & & If NO, exclude \\
$\begin{array}{l}\text { b. interaction between paramedic } \\
\text { and patient compartment and } \\
\text { equipment. }\end{array}$ & & & & \\
\hline
\end{tabular}

